\title{
ДУНД МАСШТАБЫН ГЕОМОРФОЛОГИЙН ЗУРАГ БОЛОВСРУУЛАХ АРГАЗУЙН АСУУДАЛД
}

\author{
Б.Баянжаргал ${ }^{I}$, М.НямхҮY \\ ${ }^{1}$ ШУА-ийн Газарзүй-Геоэкологийн хүрээлэн, Физик газарзүйн салбар, Монгол улс \\ ${ }^{2}$ Томскийн их сургууль, ОХУ \\ Цахим иуудан: bayanaa_geo@yahoo.com
}

Редакиид ирүүлсэн: 2017.02.26

\section{ОРШИЛ}

Геоморфологийн шинжлэх ухаан нь газрын гадаргын дотоод (эндоген) болон гадаад (экзоген) хүчний үйл явцуудыг судалдаг бөгөөд хамгийн гол нь газрын гадаргын гарал үүсэл, нас, хотгор гүдгэрийн бүтэц, хэлбэр дүрс, гадаргыг өөрчлөгч орчин үеийн үйл явцуудыг судалдаг геологи-газарзүйн завсарын шинжлэх ухаан юм [14]. Манай оронд өнөөг хүртэл уламжлагдан ирсэн голлох геоморфологийн үзэл баримтлал нь ОХУын геоморфологийн онол, судалгаатай салшгүй холбоотой бөгөөд 1960-аад оноос хойш үндэсний газарзүйчид бий болсноор өнөөг хүртэл тасралтгүй, судалгааны чиглэл нь нарийсан хөгжиж байгаа хэдий ч онолын болон зураглалын зарим дэвшилтэт аргуудаас ихээхэн хоцорсон байдал ажиглагддаж байгаа учир геоморфологийн судалгаа, морфогенетик хэв шинжийн зураглалын агуулгыг баяжуулж, өнөөгийн судалгааны арга, аргачлалд тулгуурлан шинэлэг аргазүй боловсруулах шаардлага ихээхэн тулгарч байна.

Сүүлийн жилүүдэд дэлхий дахинд геоморфологийн зураглалын шинэ систем үүсгэх асуудал хурцаар тавигдаж байгаa бөгөөд Газарзүйн мэдээллийн систем (ГМС)-д тулгуурласан орчин үеийн геоморфологийн зураглалын аргазүйг уламжлалт геоморфологийн зураг боловсруулах аргазүйтэй хослуулан нарийвчилсан геоморфологийн зураглалын шинэ систем үүсгэхэд чиглэгдэж байна [16]. Харин геоморфологийн зураг, морфометрийн ангилалыг үүсгэх үйл явц нь зөвхөн (ГМС), (ЗТС)-ийн программ хангамжийн тусламжтайгаар тодорхой нэгэн загвар үүсгэн зураглана гэдэг бол өрөөсгөл ойлголт юм [15].

Геоморфологийн дунд масштабын зураг боловсруулах ажлын хүрээнд бид өмнө хийгдсэн дунд болон бага масштабын геологи, геоморфологийн зураг болон өмнөх судалгааны ажлууд, зураглалын орчин үеийн аргазүйг уламжлалт аргазүйтэй хослуулан хээрийн судалгааны хэмжилт материал дээр тулгуурлан дээрх мэдээнүүдийг нэгтгэж, харьцуулснаар 1:500000 масштабтай геоморфологийн зураг зохиосон.

ТүлхүУр угс: Монгол орны зүҮн бүс, геоморфологийн зураг, морфогенетик хэвиинж, морфометрийн ангилал; 


\section{МАТЕРИАЛ, АРГА ЗУЙ}

Судалгааны мэдээ, материал: Бид геоморфологийн зургийг зохиохдоо өмнө хийгдсэн тодорхой масштабын геологийн ба геоморфологийн зургуудыг суурь болгон авч ашиглаж байгаа бөгөөд ингэснээр зургийн чанар илүү сайжирна гэж үзэж байна. Уг суурь зургуудад ЗХУын Шинжлэх Ухааны Академи, БНМАУ-ын Шинжлэх Ухааны Академийн (тухайн үеийн нэрээр) эрдэмтэд, судлаачдын хамтарсан Геологийн хээрийн судалгаа шинжилгээний дүнд зохиогдсон 1:1500000 масштабтай "Монгол орны геоморфологийн зураг", Монгол улсын үндэсний атласын 1:3200000 1990 он, 1:5000000 масштаб бүхий “Монгол орны геоморфологийн зураг”, (зохиогч Д.Доржготов, Үндэсний атлас, 2009), ШУА-ын Газарзүй-Геоэкологийн хүрээлэнгийн фондод хадгалагдаж буй эрдэм шинжилгээний сэдэвт ажил, төслийн хүрээнд зохиогдсон дунд болон бага масштабтай геоморфологийн зургууд, эдгээрээс гадна Газрын харилцаа геодези зурагзүйн газрын фондод хадгалагдаж буй геологийн эрэл хайгуул, геологийн зураглалын ажлын хүрээнд зохиогдсон төрөл бүрийн масштабтай геологи, геоморфологийн зургууд болон бусад судалгааны материалуудыг эx сурвалж болгон ашигласан болно.

a) Дээрх зургуудаас бидний судалгаандаа гол суурь болгон авч ашигласан зураг бол Монгол орныг бүхэлд нь хамарсан 1:1500000 масштаб бүхий "Монгол орны геоморфологи"ийн зураг юм. Энэ зураг нь тухайн үеийн нэрээр ЗХУ-ын ШУА, БНМАУ-ын ШУА хооронд байгуулагдсан Зөвлөлт-Монголын хамтарсан геологийн эрдэм шижилгээ, судалгааны экспедицийн ажлын хүрээнд зохиогдон 1987 онд Москвад хэвлэгдсэн байна. Тус зургийн эрдэм шинжилгээний редактораар Н.А.Флоренсов, С.С.Коржуев нар ажиллаж, редакцийн зөвлөлөөр Е.В.Девяткин, Н.С.Зайцев, Н.А.Корина,
Б.Лувсанданзан, Н.А.Маринов, В.Э.Мурзаева, Т.В.Николаева, И.П.Сырнев, Д.А.Тимофеев, А.Л.Яншин нар ажилласан бол зохиогчдоор Н.Б.Глуховская, В.И.Коноплева, Е.В.Девяткин, Ю.М.Клейнер,М.Е.Левинтов, С.С.Коржуев, Н.А.Корина, В.Э.Мурзаева, Т.В.Николаева, В.Ф.Шувалов, И.П.Сырнев, Д.А.Тимофеев, С.Д.Хилько, Р.А.Курушин [8] нарын ЗХУын нэрт эрдэмтэд ажиллажээ.

Эдгээр эрдэмтэдээс Монгол орны дорнод хэсэгт Ю.М.Клейнер, М.Е.Левинтов, Т.В.Николаева, В.Ф.Шувалов, И.П.Сырнев зэрэг эрдэмтэд судалгаа явуулан Хэнтийн нурууг Ю.М.Клейнер, М.Е.Левинтов, Хэрлэнгээс хойш Улз голын сав дагуу Т.В.Николаева, В.Ф.Шувалов, Хэрлэн голоос урагш Дорнод болон Сүхбаатар аймгуудын геоморфологийн зургийг И.П.Сырнев зэрэг эрдэмтэд тус тус зохиосон байна. УГ зургийн тайлбар болох "Геоморфология Монгольской Народной Республики" гэсэн бүтээл 1989 онд Москва хотод хэвлэгдсэн байна.

б) Тус судалгааны нэг гол суурь мэдээ нь БНМАУ-ын хүнд үйлдвэрийн яам, Геологийн үйлдвэрлэл шинжилгээний институтын Регионал геологийн сектор (тухайн үеийн нэрээр)-оос гаргасан “Төв ба Дорнод Монголын геологийн зураг” (зохиогч Н.Төөрүүл, 1990 он)-ийг ашигласан болно. Геологийн зургийг суурь мэдээ болгон ашиглаж буй тохиолдолд хотгор гүдгэрийн ангилал, тэдгээрийн хил заагт үл нийцэх хэдий ч үлдмэл гадаргын хэлбэр, талын дундах үлдэц хэлбэрүүд, дөрөвдөгчийн болон зарим хурдсуудыг ялгахад ихээхэн ач холбогдолтой юм.

Байрзүйн зураг: ЭнэхүY судалгаанд 1944 онд (тухайн үеийн нэрээр) ЗХУ-д зохиогдсон 1:200 000 масштабтай байрзүйн зургийг ашигласан бөгөөд 40 метрийн хаялбар татсан, уулын оройн өндөрлөгүүд, ой, зам харилцаа, хот, суурин газар, гадаргын усны сүлжээ, засаг захиргааны 
хил зэрэг үндсэн элементүүдийг агуулсан 2 хэмжээст растер мэдээ юм. Дан ганц байрзүйн зургийг аливаа морфометрийн зургийн суурь болгон ашиглахад тухайн гадаргын өндөр, хажуугийн налуу зөв гарах ч гадаргын хэлбэрүүдийн хил зааг нарийн ялгагдах боломжгүй юм.

Гадаргын тоон загвар (ГТЗ): Гадаргын тоон загвар нь байгалийн биес болон хүний үйл ажиллагаагаар бий болсон объектуудыг 3 хэмжээст огторгуйд дүрслэх, гадаргын налуу, зовхисын болон сүүдэртсэн гадаргын зургийг үйлдэх, өндрийн утгыг бусад сэдэвчилсэн давхаргуудтай уялдуулан гадаргын шинж чанарыг харьцуулах, дүн шинжилгээ хийх, янз бүрийн инженерийн ажлууд, хөрсний элэгдэл, эвдрэл болон морфологийн биетүүдийг судлах зэрэг шинжлэх ухаан, техникийн бүхий л салбарт өргөнөөр ашиглагдаж байна [1]. УГ 90 метрийн нарийвчлал бүхий ГТЗ-г ашигласнаар гадаргын хэлбэр дүрсийн тоон илэрхийлэл болох морфометрийн зургуудыг илүҮ нарийн гаргаж авах боломжтой юм [12].

\section{Ландсат хиймэл дагуулын мэдээ:} Хиймэл дагуулын мэдээг ашигласнаар дээр дурдсан (ГТЗ) ашиглан гадаргын хэлбэр дүрс бүхий (Raster) тоон мэдээлэл (өндөр, хэвгий, хэрчигдэл)-ийг буюу морфометрийн ангилалыг нарийн гаргаж өгдөг бол, Landsat 8 хиймэл дагуулын мэдээ ашигласнаар тухайн морфометрийн тоон өгөгдөл дээр гадаргын үйл явц, хэлбэр хэмжээг илүү нарийвчлалтай, зөв дүрслэх буюу морфографийн зураглалыг нэмж хийж өгч байгаагаараа илүү давуу талтай болж өгнө. Харин дан ганц хиймэл дагуулын мэдээг суурь зураг болгон ашиглавал хэлбэр дүрсийн хил зааг бодитоор гарах боловч өндрийн ялгаа төдийлөн сайн гарахгүй байх сул талтай юм.

Морфометрийн зургууд: Хотгор гүдгэрийг морфологи шинжээр нь ялгахдаа гадаргын онцлогийг харуулсан морфометрийн үзүүлэлт бүхий гадаргын өндөр, налуу, хэрчигдлийн шигүүгийн мэдээг боловсруулж шугаман матрицын аргаар морфометрийн ангилалыг хийсэн болно. ArcGIS программ-д оруулсан загварчлалыг бүдүүвч 1-д үзүүлэв.
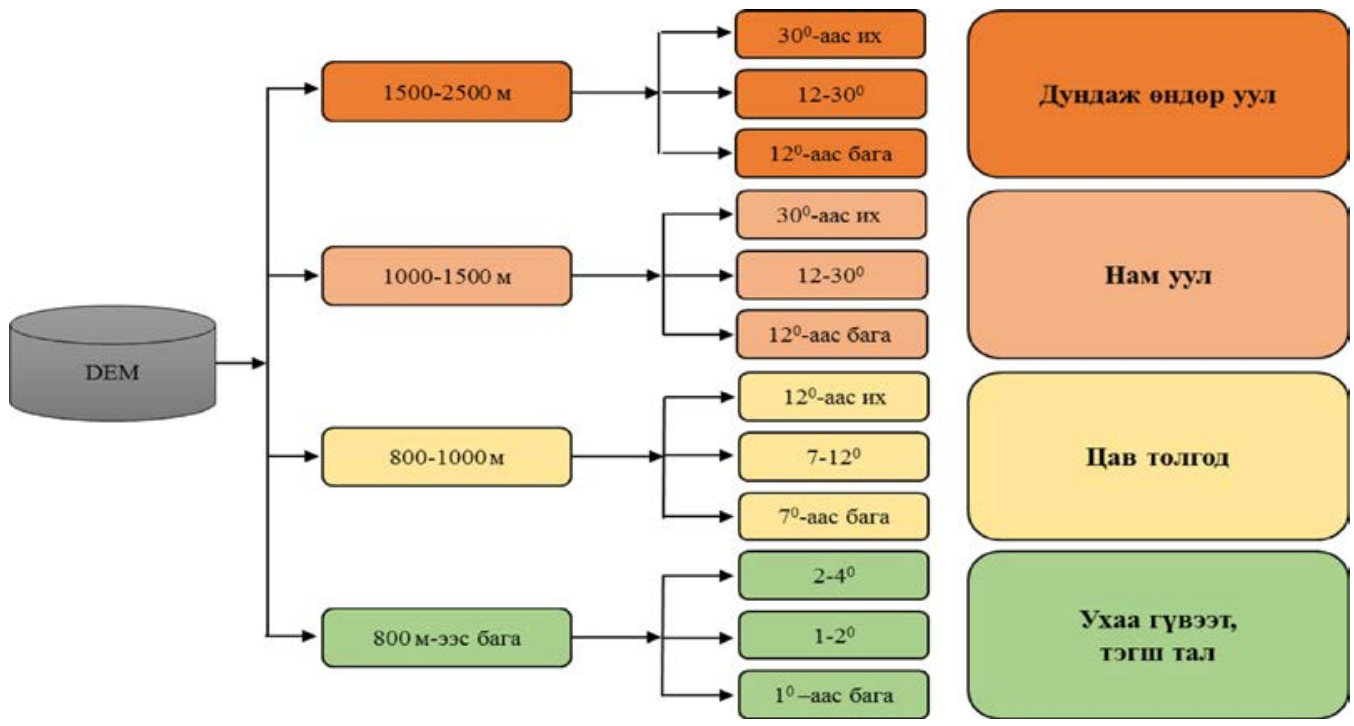

БУдүУвч 1. Морфометрийн зургийн ангилал 
Морфометрийн боловсруулахдаа (С.Жигж 1975 он) болон хэвгийн ангилал (М.Ф.Скрибном 1961 он), гадаргын хэрчигдлийн шигүүгийн ангилалыг үндэс болгон ArcGIS программын spatial analyst tools-Map Algebra хэрэглүүрийн Raster Calculator коммандаар гүйцэтгэлээ. Тус комманд нь үндсэн хэмжигдэхүүнийг ашиглан өөрийн тодорхойлох зүйлийн утгыг оруулж өгсөнөөр дурын зургийг гаргаж авах загварчлалыг бичдэг комманд юм. Тодорхойлох элементээсээ хамааран хэмжигдэхүүнээ сонгох бөгөөд хэмжигдэхүүнээ олон хувилбараар тооцон үзүүлдгээрээ бусад ангиллын аргуудаас давуу талтай байна. Тус ангиллаар уул, тал гэсэн үндсэн хоёр морфологийг ялгаж, зургийн агуулгаас хамааран үнэмлэхүй болон харьцах өндөр мөн хэвгий, хэрчигдлийн шигүу зэргээс шалтгаалан тус бүрд нь хэд хэдэн хэв шинжид ангилж болно.

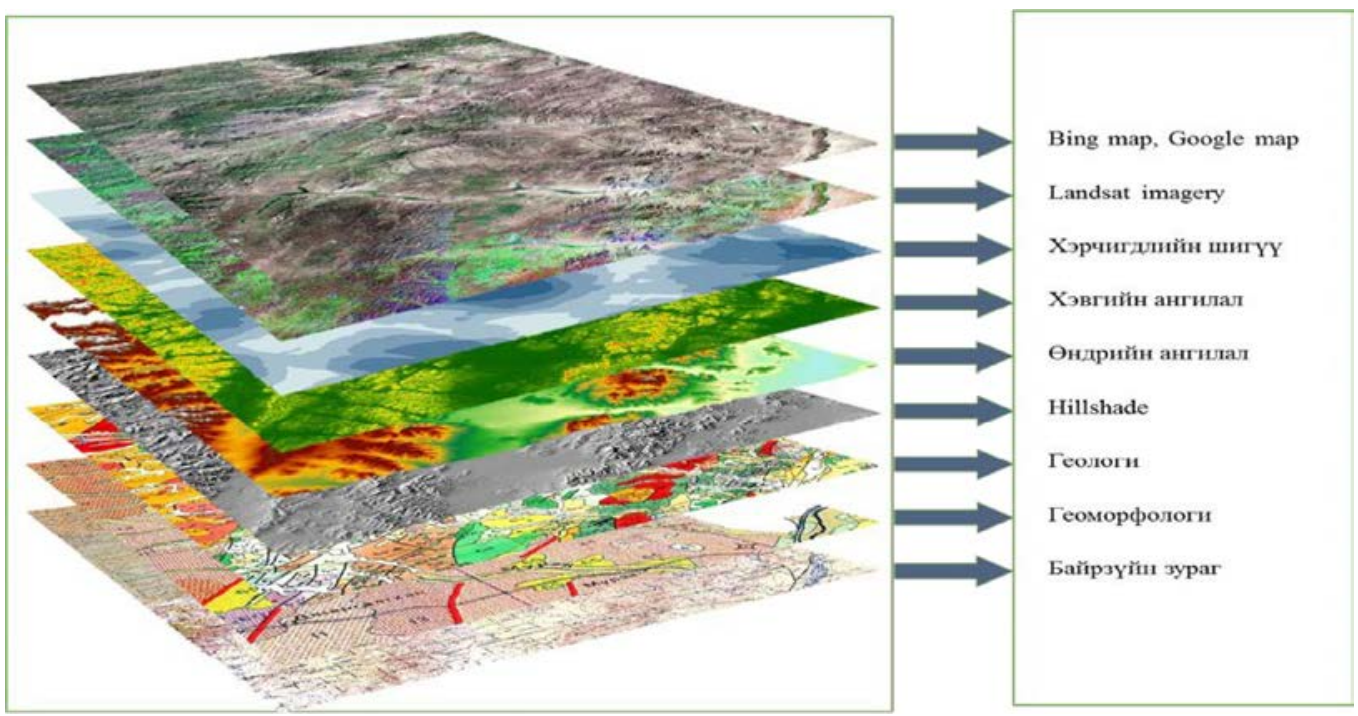

БүдҮҮвч 2. Геоморфологийн зургийн үндсэн давхрагууд

Хээрийн судалгаа: ШУА-ийн ГазарзүйГеоэкологийн хүрээлэнгийн Физик газарзүйн салбараас хэрэгжүүлж буй “Ландшафтын бүтэц, өөрчлөлт, төлөвлөлт (Монгол орны зүүн бүсийн жишээн дээр)" эрдэм шинжилгээний сэдэвт ажлын хүрээнд 2014-2016 оны хооронд нийт дөрвөн удаагийн хээрийн хэмжилт судалгаа явуулсан. Хээрийн судалгаагаар тоон болон морфологи бичиглэлийн холбогдолтой материалыг бүрдүүлснээр дунд болон том масштабын байрзүйн зурагт үндэслэн геоморфологийн аналитик төрлийн зураг зохиох боломж бий болно [18]. 
Хүснэгт : 1 Судалгааны ажлын аргазуй

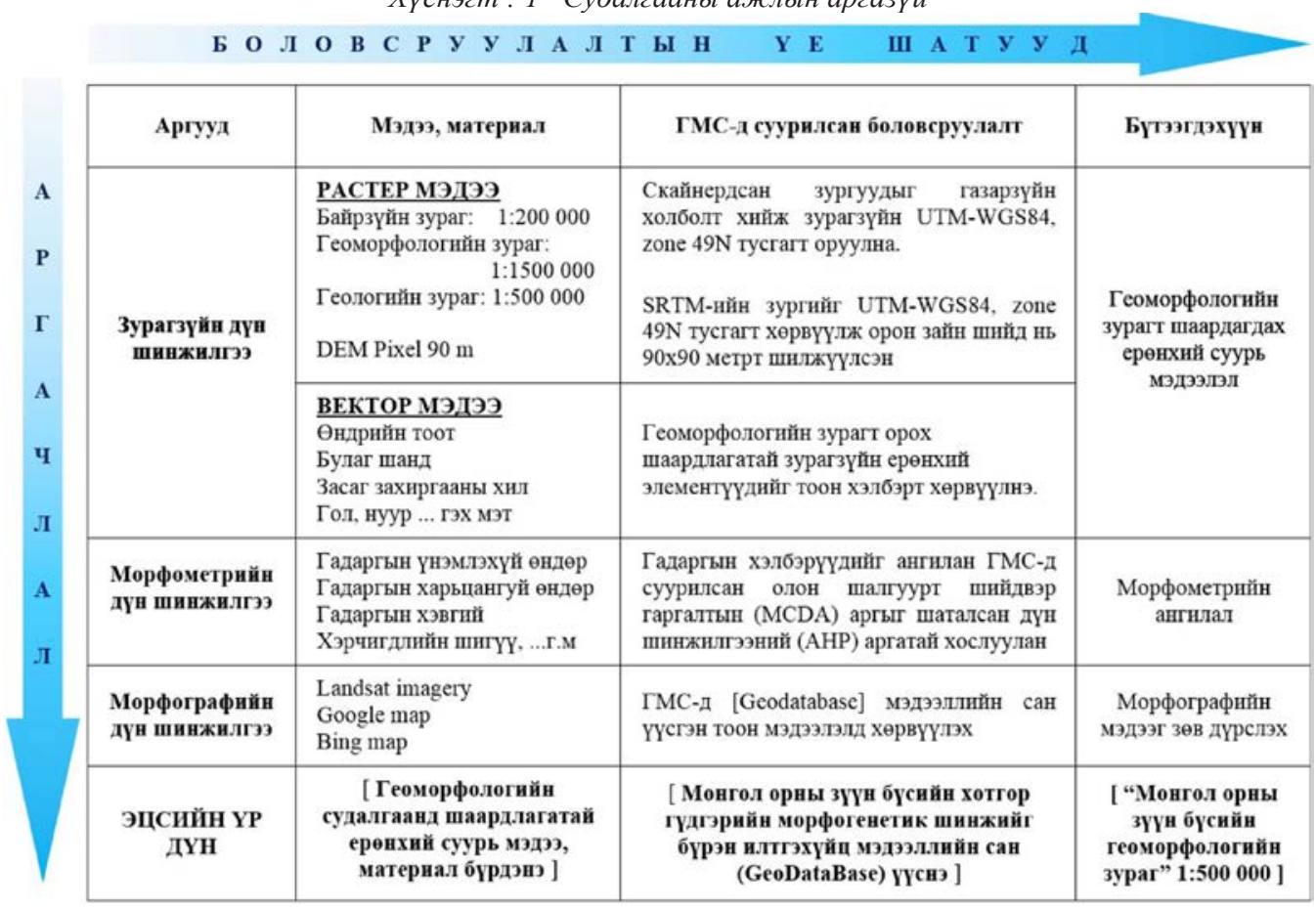

\section{ҮР ДУН, ХЭЛЦЭМЖ}

Газрын гадаргыг хэлбэр дүрсээр нь дараах байдлаар ялгаж болно. Үүнд: гадаад шинж төрхөөр нь, нийлэг (хам) байдлаар нь, хэмжээгээр нь, гарал үүслээр нь гэх мэт. Эхний гурав нь туслах чанар бүхий ач холбогдолтой бол дөрөв дэх нь үндсэн үзүүлэлт болж геоморфологийн судалгаанд хэрэглэгддэг [13].

Геоморфологийн зураг н нь Климашевскийн тодорхойлсноор харагдах байдал, хэмжээ, гарал үүсэл, нас, гадаргын хэлбэрүүдийн байршил, тэдгээрийн хоорондын хил заагийн талаарх мэдээллүүдийг өгөх бөгөөд, түүнд морфометрийн, морфографийн, морфогенетикийн, морфохронологийн мэдээлэл орох ёстой гэж дурьдсан байдаг [9] [10].

Геоморфологийн зураг зохиох асуудал 1960-аад оноос эхлэн хоёр хандлагаар хөгжиж ирсэн ерөнхий болон тусгай гэж ангилна. 1-рт, таних тэмдэг, арга зүйн хувьд анхаарч онолын түвшинд судалгаа явуулж зураглах болсон; 2-рт, геоморфологийн зургийг хэрэглээний тал руу нь хөгжүүлэх болсон [17]. Чемеков.Ю.Ф, Ганешин.Г.С зэрэг эрдэмтийн тодорхойлсоноор геоморфологийн ерөнхий зурагт гарал үүслийн түүх, хотгор гүдгэрийн нас болон бүтцийн талаар тусгах бөгөөд агуулгаар нь синтетик болон аналитик [18] зураг гэж хуваадаг (бүдүүвч 3).

Синтетик зураг: Дөрөвдөгчийн хурдас, литологи, тектоник, хөрс, ургамал, геологийн зургуудыг ашиглан байрзүйн зургийг үндэслэн суурин боловсруулалтын аргаaр зохиосон бага болон дунд масштабын ерөнхий зураг болох геоморфологийн бус хүчин зүйлүүдийг нэгтгэн харуулсан мэдээлэл бүхий зургийг синтетик зураг гэнэ. Зургийн масштабаас хамааран гарал үүслийн анги, 
групп, цаашлаад нарийвчилсан байдлаар гарал үүслийн хэв шинжүүдийг зураглана. Уулт тогтоцын онцлогийг хотгор гүдгэрийн гарал үүслээр олон төрлийн талбайг ялгана. Тухайлбал: Уулын орой хэсгийн бүслүүрийг альпын, мөстлөгийн хэв шинж, нэгдсэн ус хагалбарууд, голын хөндийн эх болон хажуунууд гэх мэт. Синтетик зурганд хотгор гүдгэрийн гарал үүслийг өнгөөр, насыг индекс болон янз бүрийн сүүдэрлэсэн өнгөөр, харин бүтцийг нь завсрын өнгөтэй тэмдгүүд болон зураасаар үзүүлнэ [18].

Геоморфологийн зураг

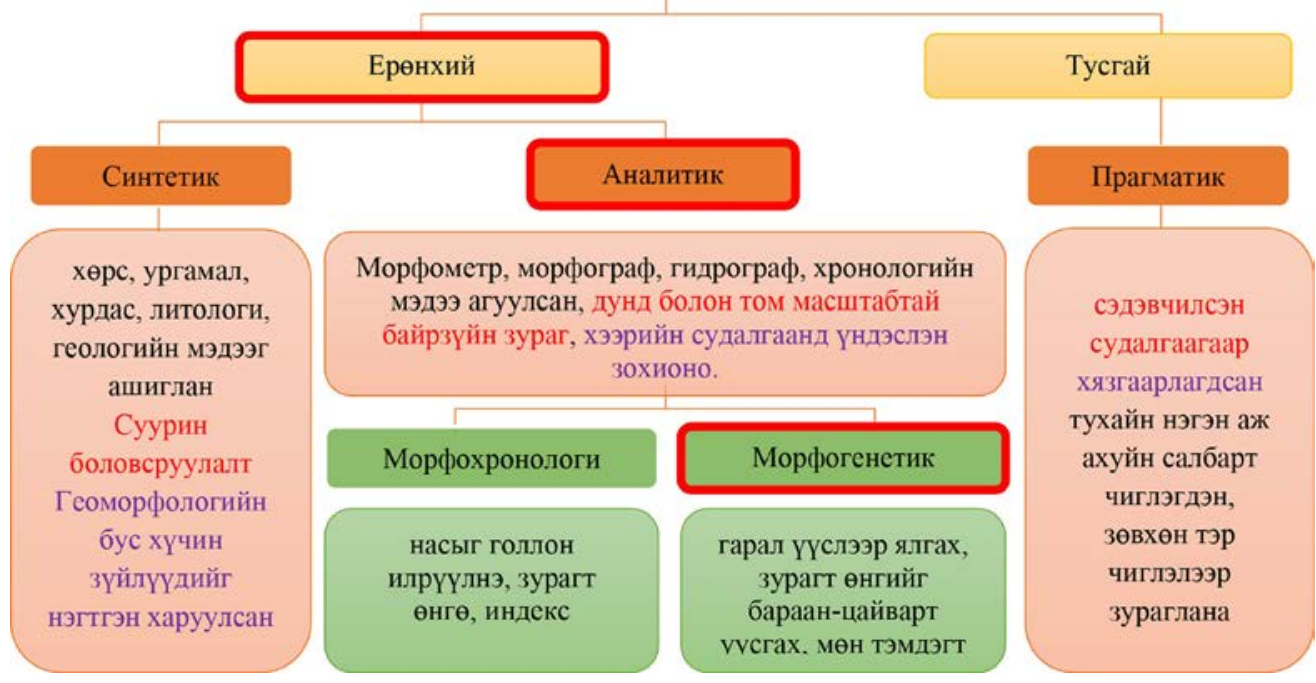

БУдҮҮвч 3. Геоморфологийн зургийн ангилал

Аналитик зураг: Нэг төрлийн гарал үүсэлтэй хотгор гүдгэрийн гадарга болон заагаар хуваан ерөнхийлөөгүй байдлаар үзүҮлсэн зургийг хэлнэ. Өөрөөр хэлбэл хэвтээ гадаргыг бүтцээр уул, тал, дэнж, ус хагалбарын, хажууг тэгш болон хэвгий гэх мэтээр ялгана. Дунд болон том масштабын байрзүйн зураг, хээрийн судалгааны мэдээллийг үндэслэн зурна. Дунд болон том масштабын аналитик зураг нь ашиглагдах эрэлт шаардлагаас хамааран гарал үүслийн болон насны аналитик зураг гэж ангилж болно. Гарал үүслийн (Морфогенетик) зурагт нэгдүгээрт гарал үүслийн мэдээллийг агуулах бөгөөд түүний хил заагийг нарийн тусгана. Гарал үүслийг тодорхойлоход түүний хэв шинжийн байдал нь чухал. Хотгор гүдгэрийн хэлбэр үүсэхэд хэд хэдэн үйл явц нөлөөлж тэдгээрээс нэг үйл явц голлох бөгөөд зурагт өнгөний шатлалаар үзүүлнэ.
Мөн идэгдлийн хажуу бүхий хөндий, эрэглэсэн хажуу, эвдрэлийн хөмөг, эртний хөндийлж... Зэрэг хэлбэрийг тэмдэгтээр Үзүүлнэ [18]. Морфохронологийн насны зурагт хотгор гүдгэрийн насны мэдээллийг голлон илрүүлнэ. Зурагт өнгөөр тэмдэглэх ба гарал үүсэл, хэлбэр дүрсийг индекс, зураас, тэмдэгүүдээр үзүүлнэ. Инженерийн бүтээн байгуулалтын барилгын үйл явцыг тооцох, тектоник хөдөлгөөний шинж байдал болон хурд, бүтцийн хэлбэрийн насыг тодорхойлоход хотгор гүдгэрийн морфохронологийн зургийг ашиглана. Бидний судалгааны эцсийн үр дүнд Монгол орны зүүн бүсийн хэмжээнд зохиогдсон аналитик төрлийн морфогенетик зарчимд тулгуурласан ерөнхий геоморфологийн зургийг боловсруулсан болно.

Монгол орны зүүн бүс нь Хэнтий, Дорнод, Сүхбаатар аймгуудыг хамрах ба нийт нутаг дэвсгэрийн хэмжээ нь 28620.9 
мян.га [5] [6] [7] талбайг эзлэх бөгөөд энэ нь Монгол орны нийт нутаг дэвсгэрийн 18.3 хувийг эзлэн оршино. Тухайн бүс нутаг нь физик газарзүйн мужлалтын хувьд ХангайХэнтийн уулархаг их мужийн Хэнтийн муж; Монголын дорнод талын их мужийн Халхын дундад ба Дарьгангын талархаг их муж, Дорнодын тэгш талын муж, Их Хянганы [2] [3] [4] мужид хамрагдана. Ландшафтын хувьд Германы эрдэмтэд монгол орны зүүн бүсийн ландшафтын голлох онцлог шинж нь хотгор гүдгэрийн хэлбэрээс болж нэг маягтай байдаг [11] гээд Хэнтий, түүний салбар уулс, Дорнод монголын бэгэлцэгт талархаг нутаг, Дорнод монголын говь гэсэн 3 том ландшафтын ялгаатай нутгууд болгон хувааж үзсэн байдаг.

Бид 2014-2016 оны хооронд Монгол орны зүүн бүсийн нутгаар хээрийн судалгаа явуулан хээрийн хэмжилт, морфологийн бичилтийг хийж, суурин боловсруулалтын явцад морфометрийн зургуудын ангилалыг боловсруулан гаргасан. Мөн өмнөх жилүүдэд зохиогдсон бага болон дунд масштабын геологи, геоморфологийн зургуудыг суурь болгон агаар, сансрын зургуудад боловсруулалт хийн мэдлэгт суурилсан ангилалын зарчимд тулгуурлан, дунд масштабын байрзүйн зураг болон хээрийн судалгааны мэдээ материалд тулгуурлан геоморфологийн зургийн мэдээллийн сан үүсгэсэн.

Геоморфологийн зураглалын ажилд зургийн таних тэмдэг боловсруулах ажил хамгийн чухал бөгөөд, зургийн таних тэмдэг нь гурван хэсгээс бүрднэ. Эхний хэсэг нь зургийн суурь буюу бүлгийг илтгэх бол, хоёр дахь хэсэг нь хэв шинжийг буюу гадаргын хэлбэрүүдийг, гурав дахь хэсгээр дэд хэв шинжүүдийг ялган харуулсан бөгөөд зургийн ангилалд өнгөний дэвсгэрийг ашигласан. УГ өнгөний дэвсгэрээр геоморфологийн зурагт нийтлэг баримтлагддаг уул, талын морфологи шинжийг ялгаж өгсөн бөгөөд гадаргын хэвгий, хэрчигдлийн шигүү, үнэмлэхүй болон харьцах өндрөөрөө болон түүн дээр явагдаж буй үйл явцуудаараа дотроо дэд хэв шинжүүдэд хуваагдана.

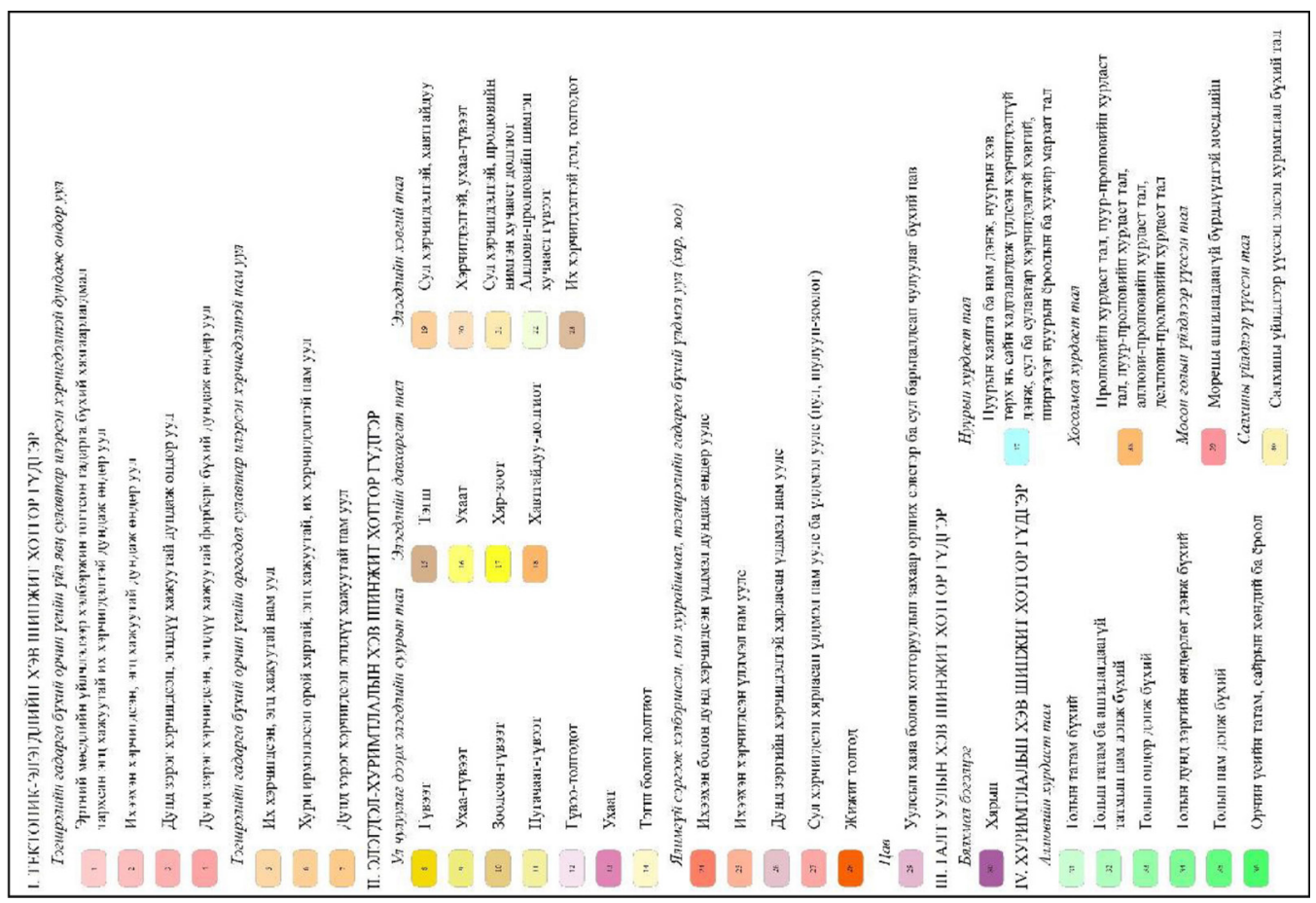




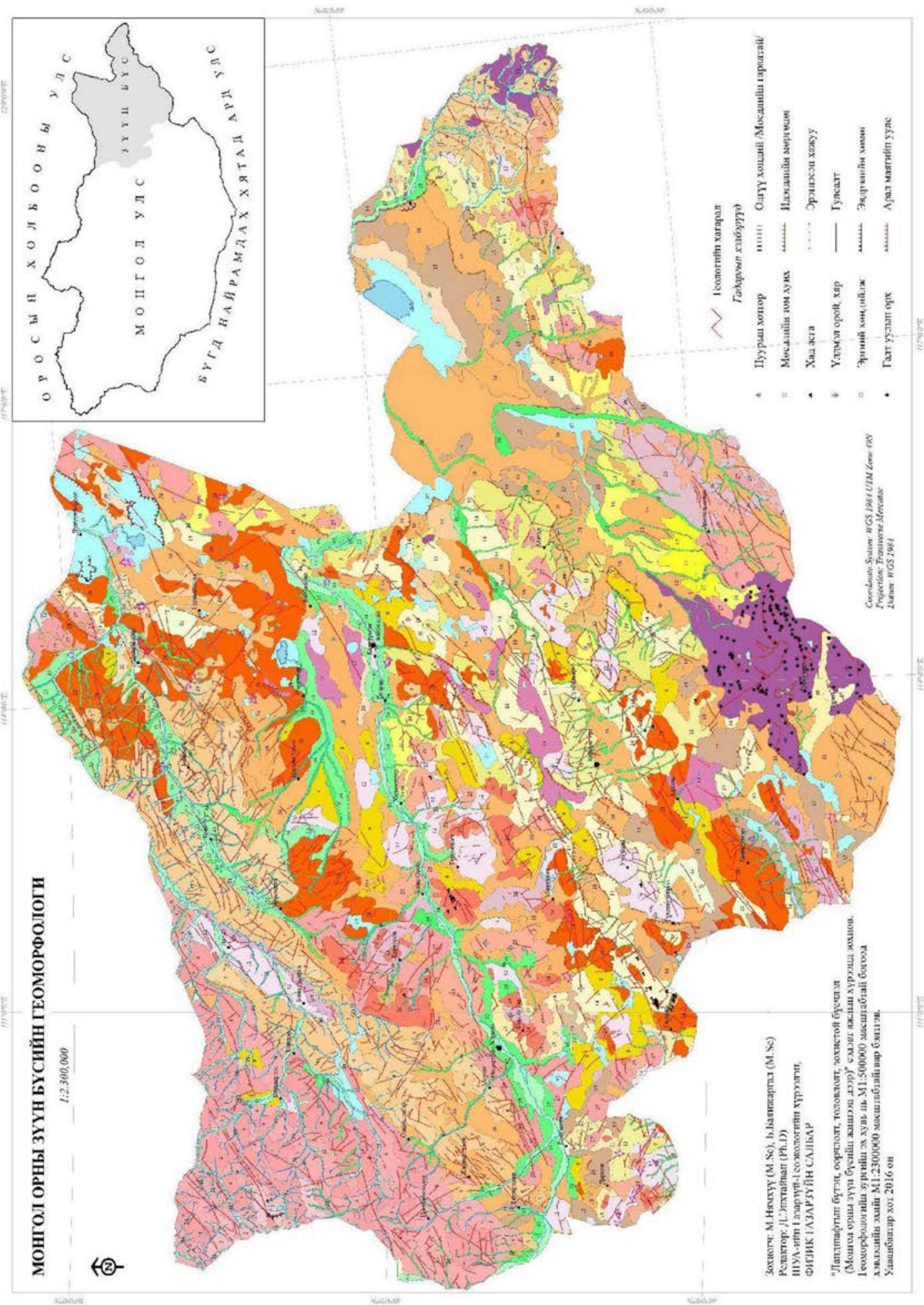




\section{ДУГНЭЛТ}

Монгол орны зүүн бүс нь геоморфологийн мужлалтын хувьд Хэнтийн мужийн Хэнтийн зүүн, Эрээнийн нурууны дэд мужууд; Монголын дорнод мужийн Улз-Хэрлэнгийн, Баруун-Уртын, ТамсагМэнэнгийн, Баяндэлгэрийн, ДарьгангаНүхт давааны дэд мужууд; Хянганы мужуудыг дамнан оршино [4]. Зүүн бүсийн хотгор гүдгэрийн морфогенетик хэв шинжийн тархалтыг авч үзэхэд тектоникэлэгдлийн хэв шинжит хотгор гүдгэр 4525.4 мян.га; элэгдэл-хуримтлалын хэв шинжит хотгор гүдгэр - 15601.1 мян.га; галт уулын хэв шинжит хотгор гүдгэр 923.9 мян.га; хуримтлалын хэв шинжит хотгор гүдгэр - 7906.9 мян.га талбайг тус тус эзэлнэ.

Тухайн зурагт нийт 12 хэв шинжийн 58 дэд хэв шинжийг ялган зурагласан бөгөөд өнгөний нийлмэл болон тэмдэгтүүдийг ашигласан. Зургийн масштабаас хамааран зурагдах боломжгүй гадаргын хэлбэрүүдийг цэг болон шулуун зураасан тэмдэгт ашигласан.

Тус геоморфологийн зургий боловсруулах явцад зургийн таних тэмдэг болох өнгөний ялгаралыг сонгоход нилээдгүй төвөгтэй байсан нь дотооддоо төдийгүй олон улсад баримталсан өнгөний код байхгүй байсантай холбоотой юм. Олон улсад нийтлэг баримталдаг хэд хэдэн код байдаг нь эндоген процессыг улаанаар, флювиал процессыг ногоон, салхин гарлын хэлбэрийг шар, антропоген хүчин зүйлийн дүнд үүссэн гадаргын хэлбэрийг хар өнгө [M.Gustavsson; E.Colstrup 2006]-өөр тэмдэглэдэг бөгөөд эдгээрээс өөр нийтлэг таних тэмдэг байдаггүй учир дотооддоо дагаж мөрддөг таних тэмдэгтэй болох хэрэгтэй байгаa нь юуны өмнө харагдаж байна.

\section{НОМ 3YЙ}

1. Амарсайхан.Д, Адъясүрэн.Ц, Саандарь.М “Зайнаас тандах судлал, газарзүйн мэдээллийн системийг байгалийн нөөциийн менежментэд аииглах нь”, УБ, 2014

2. Жигж.С “Монгол орны хотгор гүдгэрийн үндсэн хэв шинж”, УБ, 1975

3. Мурзаев.Э.М "БНМАУ (физик газарзүйн тодорхойлолт)", орчуулсан Лувсанданзан.Б, Цэвэг.Ш, УБ, 1952

4. “Монгол Улсын Үндэсний Атлас", 2009

5. Статистикийн товчоон, Дорнод аймаг, УБ, 2014

6. Статистикийн товчоон, Сүхбаатар аймаг, УБ, 2014

7. Статистикийн товчоон, Хэнтий аймаг, УБ, 2014

8. “Геоморфология Монгольской Народной Республики”, Москва, 1982

9. Шукин.И.С “Обшая геоморфология”, Москва, 1960, Том I

10. Пиотровский.В.В "Геоморфология с основами геологии” 1961

11. Рихтер.Х, Бартель.Х, Хаазе.Г “Монгол орны дорнод хэсгийн ландшафт” 1959

12. Баянжаргал.Б, НямхҮY.М "Хэнтий аймгийн нутаг дэвсгэрийн хотгор гүдгэрийн онилог, морфогенетик хэв шинж” МОГЗА, УБ, 2015

13. НямхҮҮ.М “Хөвсгөлийн баруун хэсгийн хотгор гүдгэрийн тархалт, онилог”, УБ, 2009

14. Нарангэрэл.С “ТҮйн гольнн сав нутгийн геоморфологийн судалгаа” УБ, 2009

15. Савельева.П.Ю, Мистрюков.А.А Геоморфологическая карта района Чуйской впадины горного алтая, Геоморфологическое и Картографие, Министерство образования и науки РФ Российский фонд фундаменталых исследований Институт географий РАН, Мосва, 2013 
16. Gustavsson M., Kolstrup E., Seijmonsbergen A.C., "A new symbol-and-GIS based detailed geomorphological mapping system: Renewal of a scientific discipline for understanding landscape development". Geomorphology, ELSEVIER, 2006

17. Gustavsson M., Kolstrup E., "New geomorphological mapping system used at different scales in a Swedish glaciated area". Geomorphology, ELSEVIER, 2009

18. http://science-konspect.org/? content $=2346$ 


\title{
METHODOLOGICAL ISSUES IN PROCESSING MEDIUM-SCALE GEOMORPHOLOGICAL MAP
}

\author{
B.Bayanjargal ${ }^{1}$, M.Nyamkhuu ${ }^{2}$ \\ Institute of Geography and Geoecology, Mongolian Academy of Sciences \\ Tomsk State University, Russia \\ E-mail: bayanaa_geo@yahoo.com
}

In order to classify morphology and morphogenetic features of Mongolian eastern region, it is based on the field study measurements, high accurate digital elevation model (DEM), large scale topographical map and targeted to use mapping methodology on chosen territory. We have used geomorphological mapping traditional method and modern advanced technology for this study. As a result, we have received more precise results.

According to describing of Mechislav Klimaschewski: Geomorphological map must include appearance, size, origin, age, location of morphology, some information of boundaries between them, also morphometry, morphography, morphogenetic and morph chronical information. As a result of this study, we have mapped geomorphological map based on principle of morphogenetic.

This map is consists of 4 groups, 12 features, 58 sub features of origin, and map legends are imaged by map symbols and different colors. Depending on map scale, some morphological features which are impossible to denote are denoted by point and line symbols.

Keywords: Mongolian eastern region, geomorphological map, morphogenetic features, morphometric classification; 